\title{
Developing a Proficient and Motivated Teacher Workforce in the Philippines
}

\section{Introduction}

Over the last decade, research from many different countries has demonstrated the important role played by teachers in increasing students' learning and improving their academic performance.' Studies from countries as different as the US and Indonesia have shown the enormous benefits that follow from having adequate and effective teachers working in a country's schools. In Indonesia, a value-added analysis of student learning outcomes found that the more teachers know, the greater the improvements in the learning competencies of primary and junior secondary students. ${ }^{2}$ In the US, better teaching in elementary and secondary schools has been shown to increase students' college participation rates, raise their subsequent earnings, and improve other long-term outcomes. ${ }^{3}$

Providing teachers with good quality professional development opportunities has been shown to be an effective way of increasing their competencies and improving student learning outcomes in many different settings. A series of systematic reviews have been undertaken recently to assess the impact of different interventions on student learning outcomes in developing countries. ${ }^{4}$ One of the most consistent findings from these reviews has been the positive and significant impact that interventions to strengthen teaching practice, introduce innovative instructional methods, and strengthen teachers' subject knowledge can have on student learning. However, in many countries, such professional development opportunities frequently fail to meet even minimum levels of quality and fall short of what teachers want and need.

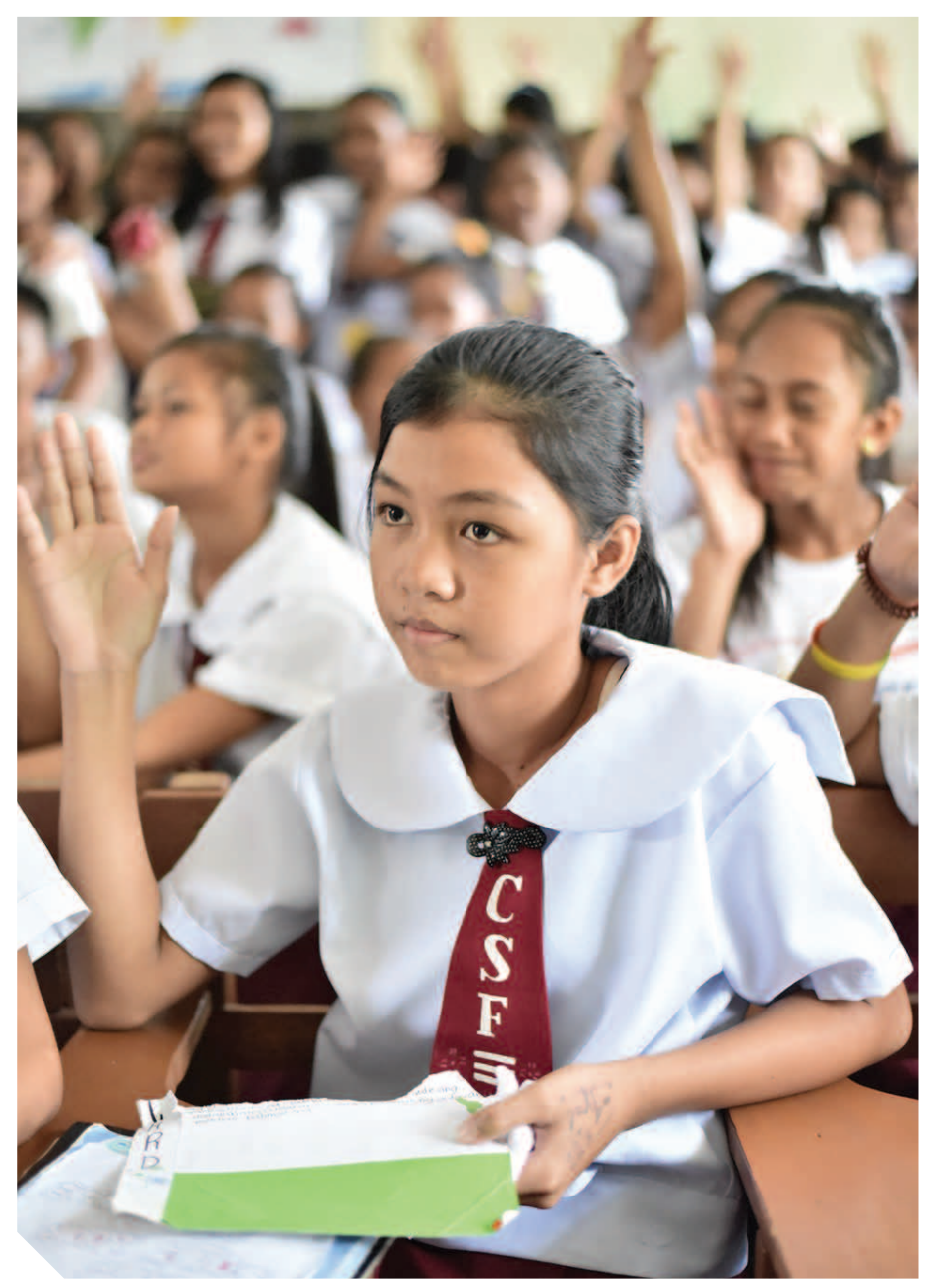

This note is part of a series outlining analysis and results from the Philippines Public Expenditure Tracking and Quantitative Service Delivery Study conducted by the Department of Education and the World Bank with the support of the Australian Government through the Australia-World Bank Philippines Development Trust Fund. 


\section{Box 1: The Philippines Public Education Expenditure Tracking and Quantitative Service Delivery Study}

The aim of the Philippines Public Education Expenditure and Quantitative Service Delivery Study has been to answer four main questions on the use of the public education budget:

1. Resource flow, management, and control. What factors prevent resources from reaching their intended destination in a timely and transparent manner?

2. Existence, use, and financing of inputs at the school level. Do schools have access to essential inputs and how effective are the systems that govern their use?

3. Equity. How do the resources available to schools and the systems that manage these resources differ among regions and socioeconomic groups?

4. School performance and resources. How and why does the performance of schools differ and what drives those differences?

The study has tracked over 80 percent of the national government education budget (including teacher salaries and training, school maintenance and operating expenses, construction, and learning materials) as well as local government spending on basic education.

In order to assess how funds flow and how they are used at the school level, the study team conducted a nationally representative survey of government institutions and public schools in the last quarter of 2014. The Autonomous Region in Muslim Mindanao was excluded from the study because government funds for this region are managed separately and flow to schools through a different mechanism. In addition, integrated schools (which offer both elementary and high school education) and schools that did not have final grade elementary and high school students were excluded from the sample, primarily because the study aimed to measure outcomes at the end of elementary school and at the end of high school.

The sample for the survey included all regional offices of the Department of Education (DepEd) and the Department of Budget and Management (DBM), 51 division and 113 district offices of DepEd, 54 district engineering offices of the Department of Public Works and Highways, 74 provincial and city/municipality local governments, 249 public elementary schools, and 200 public high schools. At the school level, interviewers administered a questionnaire to each parent-teacher association, assessed the competencies of approximately 1,500 teachers, and interviewed 2,200 student households.

The data collected were used to explore the systems that govern the use of public funds and to assess how the availability of resources differed among schools. The study team combined information on the flow of funds to schools with information on school characteristics and quality to evaluate how financing and governance affected school performance.

These reviews also highlight the importance of teachers' motivation in determining their effectiveness and ultimately in improving the learning outcomes of their students. They found some evidence that introducing financial incentives for teachers based on individual teacher or school performance can increase the amount that students learn.

The purpose of this policy note is to provide an overall picture of teacher competencies in the Philippines and to assess whether the country's professional development systems deliver the training opportunities that teachers need to be effective. ${ }^{5}$ The findings reported in the note are based on a comprehensive survey of the public education system that tracked public education expenditures and assessed the quality of education services (see Box 1).

The note shows that elementary and high school teachers' subject knowledge is weak and a major constraint to improving student performance. While public spending on professional development activities has been increasing, 
these findings highlight the need to significantly expand in-service training opportunities and tailor them more closely to teachers' needs. Moreover, systems for professional development, teacher performance monitoring and incentives need to be aligned to improve teacher competencies and motivation.

\section{The Quality of Elementary and High School Teachers}

The competency of teachers both in terms of their subject matter knowledge and instructional methods has been shown to be an important determinant of student learning outcomes in the Philippines. ${ }^{6}$ However, getting an accurate measurement of the competencies of teachers is challenging. The Department of Education (DepEd) along with experts at the Philippines Normal University (PNU) and their partner university in Australia have developed a set of teacher competency assessments for the new K to 12 curriculum (Box 2). All the assessments have gone through a rigorous design and validation process to ensure that they accurately measure a teacher's knowledge of the subjects required to teach in elementary and high schools. In addition to subject content tests, the PNU also designed a shorter version of DepEd's Teacher Strengths and Needs Assessment (TSNA). This self-assessment tool gives a picture of a teacher's pedagogical competence according to DepEd's own National Competency Based Teacher Standards (NCBTS).
These assessments have been used by the PETS-QSDS study to provide evidence on levels of teacher competency in public elementary and high schools.

According to the results of the PETS-QSDS exercise outlined in Box 2, knowledge of subject matter among elementary and high school teachers is low in most subjects. With the exception of English at the elementary school level, the average elementary or high school teacher could answer fewer than half of the questions on the subject content tests correctly (Figure 1). For example, the median mathematics teacher in high school was able to answer only 31 percent of the questions completely correctly. Since these tests are closely aligned with the curriculum, the results suggest that teachers face significant challenges in teaching a considerable portion of the current K to 12 curriculum. In other words, the findings point to the need for significant improvements in teachers'skills and subject knowledge if they are to have a full command of the curriculum and to provide effective instruction in the classroom.

To explore why so many teachers were unable to answer the assessment questions correctly, the PETS-QSDS study used a partial credit model to look more closely into the incorrect answers that teachers gave. For example, teachers were given a choice of four possible answers to each multiple choice question, and the three incorrect choices reflected different levels of understanding on the part of the respondents (Box 2).

\section{Figure 1: Teachers' Performance on Content Knowledge Assessments Was Poor}

Percentage of questions answered correctly by the median teacher (binary scoring method), 2014

\section{Grade 6 elementary school teachers}

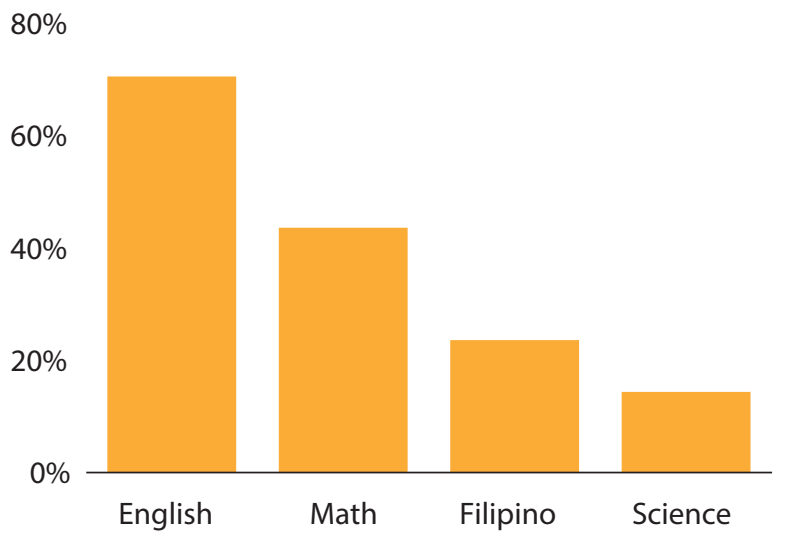

Grade 10 high school teachers

$80 \%$

$60 \%$

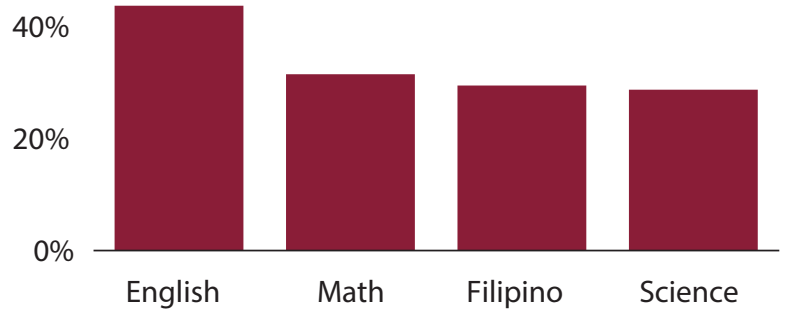

Source: PETS-QSDS teacher content knowledge assessments. 


\section{Box 2: PETS-QSDS Approach to Assessing Teachers}

As part of the PETS-QSDS study, a nationally representative sample of 377 Grade 6 (elementary) teachers and 946 Grade 10 (high school) teachers took two assessments:

1. A subject-based content assessment for measuring teachers' knowledge of the content of the K to 12 curriculum in English, Filipino, Mathematics, and Science. The assessments consisted of multiple choice and open-ended questions. Grade 6 teachers were randomly assigned to complete one subject assessment, whereas Grade 10 teachers completed the test in the subject that they taught.

2. A short form of the Philippine government's Teacher Strengths and Needs Assessment (TSNA) based on the National Competency Based Teacher Standards (NCBTS). The TSNA assesses a teachers' own perceptions of their pedagogical competence in the seven NCBTS domains: (i) social regard for learning; (ii) learning environment; (iii) diversity of learners; (iv) curriculum; (v) planning, assessing, and reporting; (vi) community links; and (vii) personal growth and development. Teachers were asked to rate their own level on a four-point scale from low to high on a set of statements related to the seven domains.

The content tests were drawn from larger assessments used by the Research Center for Teacher Quality (RCTQ) at the Philippines Normal University. The results of the PETS-QSDS tests are consistent with findings from a larger regionally representative study conducted by the RCTQ.

Two scoring rubrics were used for the content tests:

1. Binary credit - questions were marked either correct or incorrect.

2. Partial credit - each question was scored on a four-category scale, with 1 being "incorrect," 2 being "displays some understanding, skill, and knowledge," 3 being "displays a higher level of understanding, skill, and knowledge," and 4 being "completely correct."

Responses coded 1, 2 or 3 on the partial credit scale were recorded as 0 on the binary scale and those coded as 4 on the partial credit scale were recoded to 1 on the binary credit scale. In the case of the multiple choice items, the choices provided represented different levels of the teacher's understanding of the competency being tested. For open-ended questions, the graders marking the tests interpreted written responses according to the four-point scale.

The binary credit scores provided a clear picture of whether teachers displayed a thorough understanding of the competencies included in the curriculum. The partial credit scale, on the other hand, provided a more detailed assessment of how far teachers were from a complete understanding of the underlying competencies and from having the necessary knowledge to teach effectively.

Given the assessment categories used by teachers to assess their own competencies, the TSNA was scored using a rubric similar to the partial credit scale. To account for differences in the difficulty of test items, a one-parameter Rasch model was used for both the subject content tests and the TSNA to transform the raw test scores into scores (logits) that ranked teachers according to their underlying ability.

Full details of the instruments used and the methods for analyzing the data are available in RCTQ and SiMERR, (2015) "PETS-QSDS final report".

The results of the partial credit scoring model showed that many teachers had some understanding of the subject area but lacked the higher order problem-solving skills necessary to teach the curriculum effectively. The model showed that, in most cases, teachers do have some understanding, skill, and knowledge in all curriculum areas but not necessarily enough to answer all of the question correctly. For example, the scoring for a relatively difficult test question showed that, 
while only 20 percent of high school science teachers got the question completely correct, another 64 percent chose an answer that demonstrated some useful knowledge in the curriculum area covered by the question (Figure 2). These more detailed results can inform efforts by DepEd to develop professional development activities that are more closely aligned with the existing knowledge and abilities of the country's teachers.

The study team performed a simple regression analysis to explore associations between teachers'scores on the subject knowledge assessment and their characteristics. ' Overall, they found that teachers' performance was not associated with their levels of education or experience. For example, the scores of teachers who had obtained a postgraduate qualification did not differ from those of teachers with only a bachelors' degree in a statistically significant way. Although newly hired teachers tended to do less well than existing teachers in most of the subject-specific tests, these differences were not statistically significant either.

The better-performing high school teachers tended to teach in schools that serve better-off students. The PETS-QSDS survey included a nationally representative sample of public elementary and high school student households. Using information on consumption and asset ownership that was collected in the survey, it was possible to rank student households by estimated levels of per capita household consumption. ${ }^{8}$ Using this indicator, it was possible to look at differences in the performance of teachers who were teaching different kinds of students. The key finding was that, in high school, poorer students tended to be taught by less competent teachers except in English. ${ }^{9}$ At the elementary level, no clear pattern emerged although poorer students tended to be taught by teachers that performed better on the Filipino test.

Teachers themselves generally assess their levels of skills as satisfactory. A shorter version of the TSNA self-assessment was given to the same teachers who completed the subject matter tests. These teachers were asked to rate their own skill level in seven domains that included social regard for learning (including punctuality and the use of information from a variety of sources for learning), the learning environment (maintaining a safe and conducive learning environment and setting high expectations for learners), and the curriculum (demonstrating a mastery of the subject and communicating learning goals). ${ }^{10}$ The teachers were given a set of statements related to each domain and were asked to rate themselves on a scale of 0 (low) to 3 (high). On average, teachers rated themselves above 2 (satisfactory) on all domains. Moreover, there were no significant differences

\section{Figure 2: Despite their Overall Poor Performance, Teachers Have Some Relevant Skills and Knowledge Upon Which to Build}

Percentage of Grade 10 science teachers by their responses to easy and hard test questions, 2014

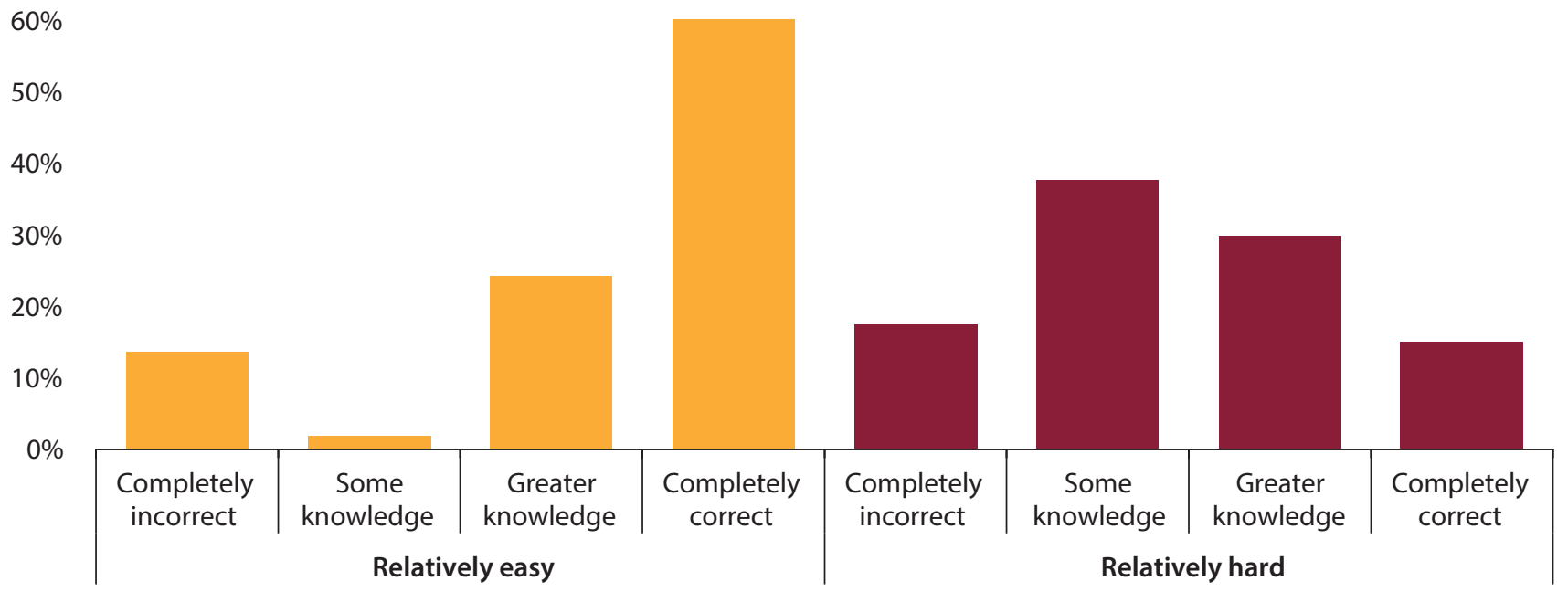

Source: Results of the PETS-QSDS Grade 10 teacher content knowledge assessment.

Note: The easy question is in the lowest quartile of Rasch model scores while the hard question is in the highest quartile of difficulty. 
in the self-reported levels of strengths and weaknesses between teachers in elementary schools and those in high schools.

The teachers generally felt that they were weakest in the planning and the learning environment domains. The study team developed a common scale that accounted for the difficulties involved in obtaining the various competencies measured by the statements in the assessment. This made it possible to compare the relative strengths and weaknesses of teachers (Figure 3) and revealed that both elementary and high school teachers tended to rate their competencies in planning as the weakest. This domain includes competencies associated with instructional planning, the use of different assessment strategies to evaluate students' learning, and providing feedback to learners. The teachers also felt that they were weak in the competencies associated with the learning environment such as communicating high learning expectations and the ability to deal with students' behavioral issues.

Despite having had relatively low scores in the subject matter tests, teachers rated their competencies in the curriculum domain, including subject-matter knowledge, very highly (Figure 3). Competencies in this area include demonstrated mastery of the subject area and the appropriateness of the teaching methods used for different learning activities. Teachers rated their competency in this area higher than on any of the other competencies in the national standards. These results are in stark contrast with the same teachers' results on the objective subject matter tests (Figure 1). This mistaken perception of their own skills on the part of teachers highlights the difficulty they are likely to have in assessing their students' performance as well.

The results of the PETS-QSDS assessments suggest that selfassessments of teachers' strengths and weaknesses may not be a good basis on which to plan professional development activities. Simple correlation coefficients among the elementary school teachers who took these tests showed a weak relationship between the teachers' self-assessment ratings and the subject-matter test scores. In most cases, these correlations were not statistically significant. There was more variation in the picture for high school teachers. The self-assessment ratings for Filipino and Mathematics teachers were generally positively correlated with their subject matter test scores, and these associations were statistically significant. However, similar correlations for English and

\section{Figure 3: Teachers Assess Their Weakest Skills as Those Associated with the Learning Environment and Planning and Assessment}

Average self-assessment scores on national competency-based standards, 2014

4

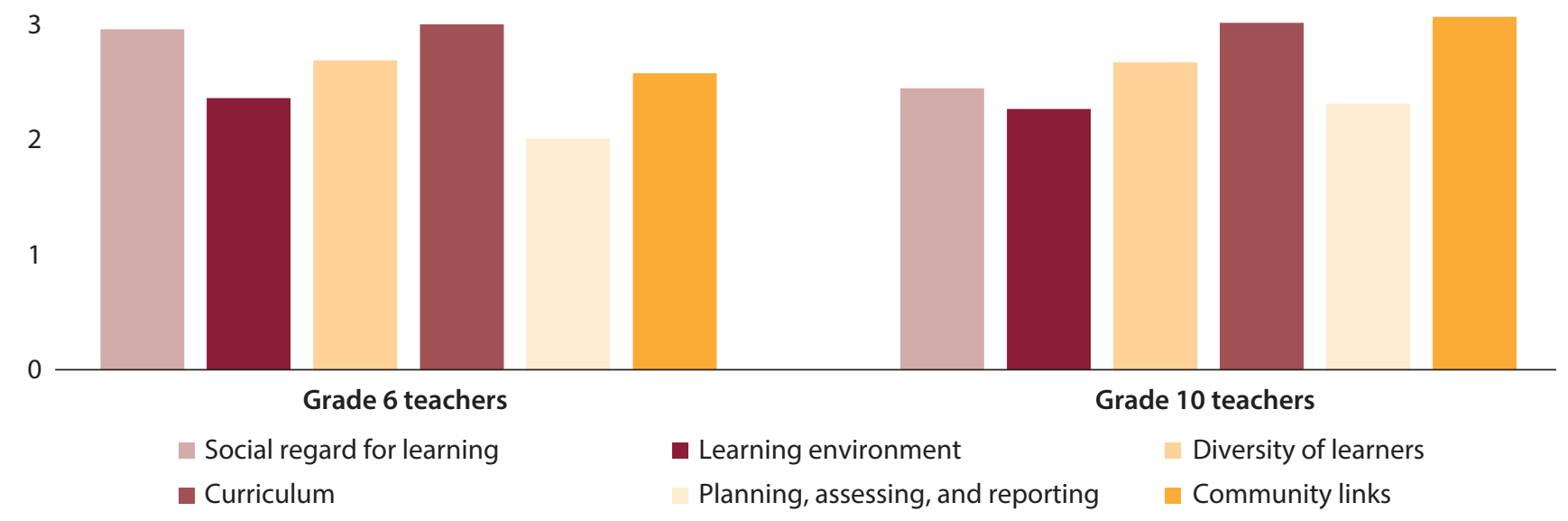

Source: Results of the PETS-QSDS Grade 6 and 10 teacher strengths and needs assessment.

Note: The mean of the Rasch scores has been shifted by five units to report positive averages to aid interpretation. Higher scores are related to higher selfassessed skill levels in the particular domain. 
Figure 4: Most Teachers Receive Some In-service Training but Only for Short Periods

Percentage of teachers receiving in-service training and duration of all training received, 2013

\section{Participation, \% teachers}

$90 \%$

$80 \%$

$70 \%$

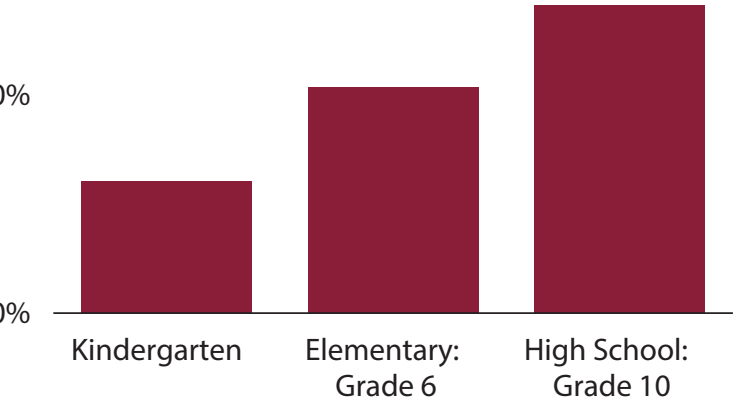

Source: PETS-QSDS national survey - teacher-level data.

Science teachers were generally not statistically significant. In all cases, the strength of the association was relatively weak, which casts doubt on the usefulness of existing selfassessment tools to plan teachers' in-service training

\section{Supporting Teachers in School through Professional Development}

High quality and regular professional development opportunities are needed to address the weaknesses in the competencies of the existing teacher workforce. Studies from both developing and developed countries have shown that, when well-designed, in-service teacher training can increase teacher's content knowledge, improve their methods of instruction, and ultimately improve student learning outcomes." This section looks at in-service teacher training in the Philippines and assesses the systems that plan and finance these opportunities.

\section{Incidence and Intensity of Training}

The percentage of teachers in the Philippines who receive some annual in-service training is high even when compared to levels in high-income developed economies. The PETS-QSDS survey collected detailed data on the in- service training received by sampled teachers in 2013 and 2014. The data revealed that more than three-quarters of all basic education teachers had received some in-service training (Figure 4). More high school teachers had received in-service training than elementary or kindergarten teachers. The team compared these rates with the rates of professional development activities for teachers in 34 OECD countries collected in the Teaching and Learning International Survey (TALIS). ${ }^{12}$ On average, 89 percent of public school lower secondary teachers in these countries participated in professional development activities in 2013. Participation rates in the Philippines were comparable although they were higher in Malaysia, an East Asian country with similar levels of student learning as the Philippines.

While the majority of teachers in the Philippines received some professional development training, it was less than in most other countries. In 2013, the average Grade 10 high school teacher received approximately five days of in-service training. The PETS-QSDS survey was conducted at the end of 2014, which was approximately two-thirds of the way through the school year, and there were signs that the length of in-service training had increased over the 2013 level. For example, Grade 10 high school teachers had already received seven days of in-service training by the time of the survey. However, even this level is relatively low. The average lower secondary teacher in the OECD TALIS study received approximately eight days of professional development a 
year..$^{13}$ Given the higher levels of teacher competency in OECD countries, it might be expected that the duration of in-service training in the Philippines should be longer.

The most common kind of training received by elementary and high school teachers in the Philippines was in subject content. Approximately, 40 percent of elementary and 30 percent of high school teachers reported attending some subject-based training during the 2013 school year. Training in methods of instruction and teaching was also relatively common with around 12 percent of elementary and high school teachers attending this kind of training in 2013.

The training usually took place in schools and was frequently conducted by school principals. About a half of all elementary teacher training and two-thirds of high school teacher training conducted in 2013/14 took place in schools. DepEd division offices were also commonly used to conduct training, while DepEd district-level offices were frequently used for training for elementary school teachers. Just over half of all training sessions for elementary school teachers and 39 percent of sessions for high school teachers were conducted by DepEd division, region, or central-level staff. School principals were also involved, conducting 32 percent of all training for elementary school teachers and 44 percent of training for high school teachers. Outside experts were used sparingly, accounting for less than 15 percent of training sessions.

Teachers were generally positive about the training that they had received, but a significant proportion felt that they needed more. Elementary and high school teachers ranked over 80 percent of the training that they received in 2013 as extremely useful. ${ }^{14}$ However, approximately 40 percent of teachers interviewed said that they needed more and better quality in-service training to improve their classroom teaching (Figure 5).

Systems at the school level to support teachers and identify their professional development needs do not seem to be working well. Each teacher is expected to complete an Individual Plan for Professional Development (IPPD) to outline their professional development needs. In preparing these plans, teachers are expected to use a toolkit prepared by DepEd which utilizes a teacher's own strengths and needs assessment using the TSNA. School principals are then expected to aggregate the needs of individual teachers into a School Plan for Professional Development (SPPD) and to submit it to the DepEd division office, which prepares a division-level master plan for professional development.

In the PETS-QSDS team's interviews with teachers, it became clear that a significant proportion of teachers and schools had not developed professional development plans. For example, a quarter of high school teachers had never prepared an individual professional development plan (Figure 6). Even the plans that had been prepared were over a year old on average for both elementary and high school teachers. ${ }^{15}$ School plans were even less common, with a

\section{Figure 5: A Large Proportion of Teachers Felt They Needed More In-service Training Opportunities}

Percentage of Grade 10 high school teachers by the type of additional support that they most need to improve their classroom teaching, 2014

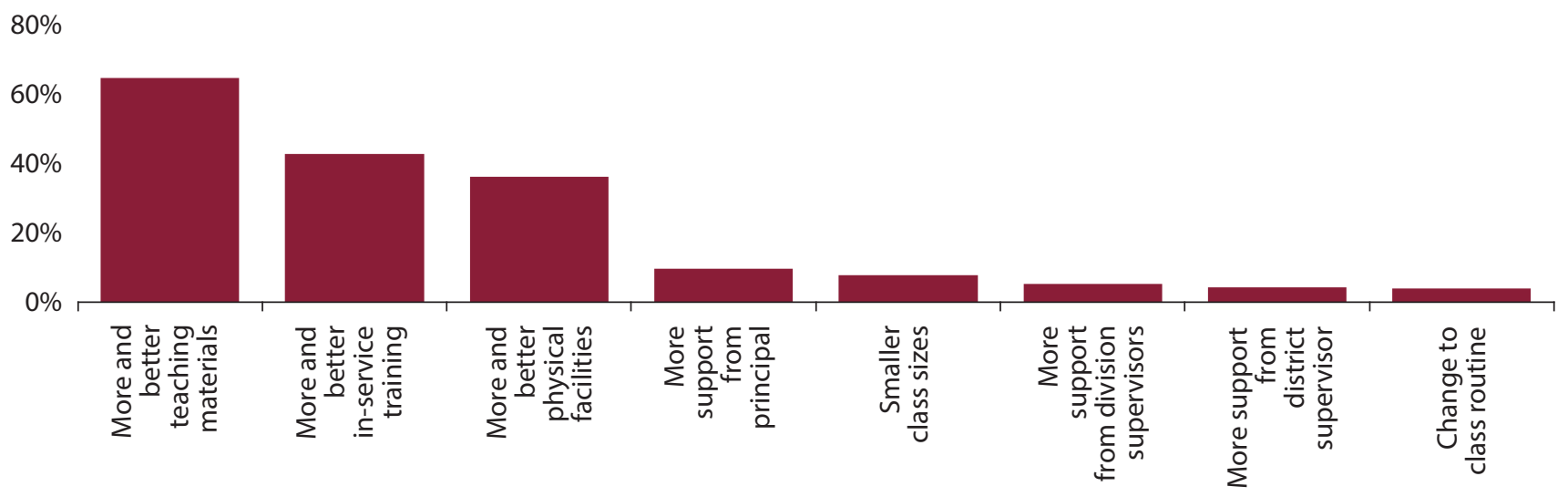


Figure 6: The Implementation of Systems to Identify Professional Development Needs is Weak

Percentage of school staff completing professional development plans and the time since one was completed
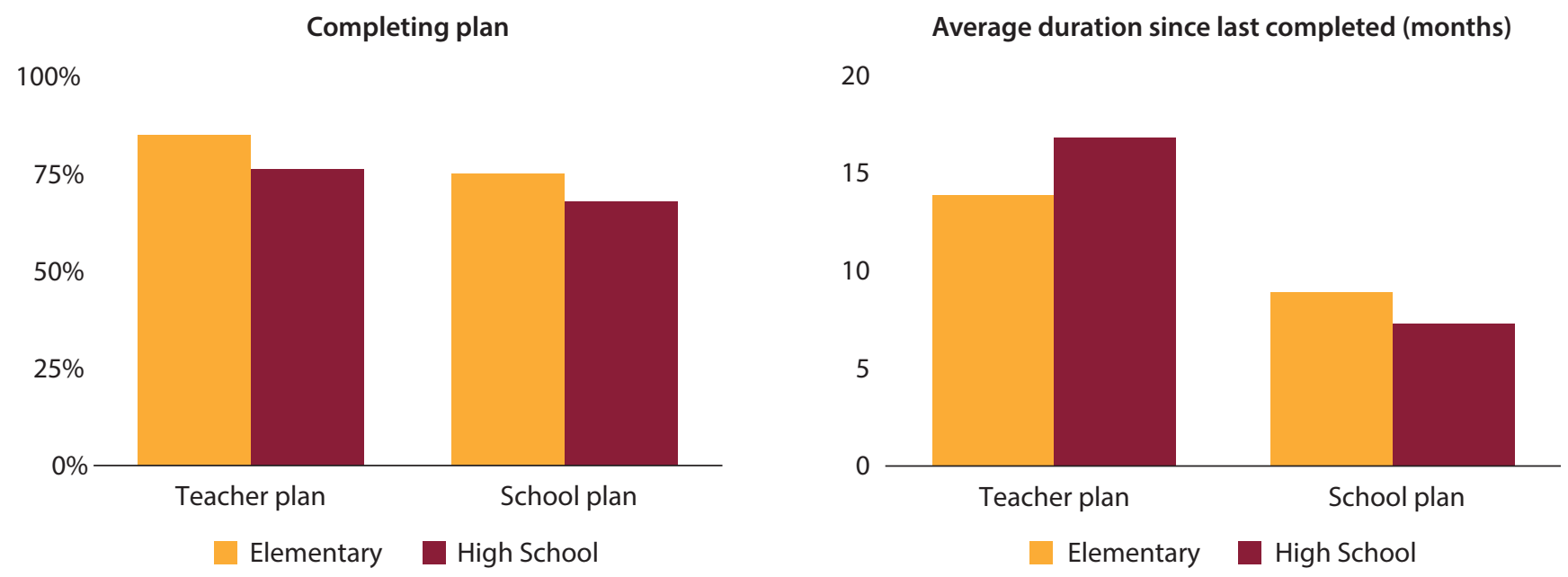

Source: PETS-QSDS national survey - teacher-level and school/principal data.

Notes: Information on teacher plans taken from interviews with Grade 6 (elementary) and Grade 10 (high school) teachers.

quarter of elementary school principals and nearly one-third of all high school principals reporting that they had never prepared one. While the teachers and school principals that had completed plans agreed that their training was related to the goals set out in their plans, the PETS-QSDS training data show that the type and duration of training was more or less the same for those teachers who had filled out an IPPD and those who had not.

Other mechanisms to link teacher training to need also did not appear to differentiate training between teachers with different needs. The length and type of training that teachers received did not vary significantly by their characteristics such as levels of experience or qualifications. Moreover, the number of days of training received by teachers did not differ in line with their performance in the assessments administered as part of the PETS-QSDS survey. This concurs with other findings that have shown that most teacher training in the Philippines is based on a mass training model that provides all teachers with very similar training. Only 17 percent of school division superintendents (SDSs) said that division offices based their decisions about teacher training on the actual needs of teachers within the division. The majority of SDSs said that most division-level teacher decisions about training were based on the SDS's own assessment of needs or on directives from DepEd's central office.
Support from school principals for teachers' professional development also tended to vary considerably among elementary and high schools. Only two-thirds of Grade 10 teachers in high schools reported that the school principal had spent a full period in their classroom over the course of the whole 2013 school year. (The equivalent figure for Grade 6 elementary teachers was much higher at 82 percent.) When principals did observe classroom teaching, most of them gave written comments to the teacher, mostly focused on the teaching method used. Only around a quarter of comments concerned the teacher's knowledge of the subject content even though the PETSQSDS assessments indicated that teachers have major weaknesses in this area. ${ }^{16}$

\section{Funding In-service Teacher Training}

In an effort to provide more and better in-service teacher training, DepEd has begun to increase the budget allocation for human resource training and development (Figure 7). Human resource training and development (HRTD) funds are the main professional development resources provided by DepEd. Most HRTD funds are spent on in-service training for teachers, but they are also used to provide training for non-teaching personnel. After having risen gradually since 2005 , the budget for all in-service training nearly doubled to PHP 1.9 billion in 2014 to allow 
Figure 7: The Budget for In-service Training Has Increased Recently but Utilization Rates Are Frequently Low Appropriations, allotments, obligations, and utilization rates for HRTD funds (PHP billions in 2014 constant prices), 2005-2014
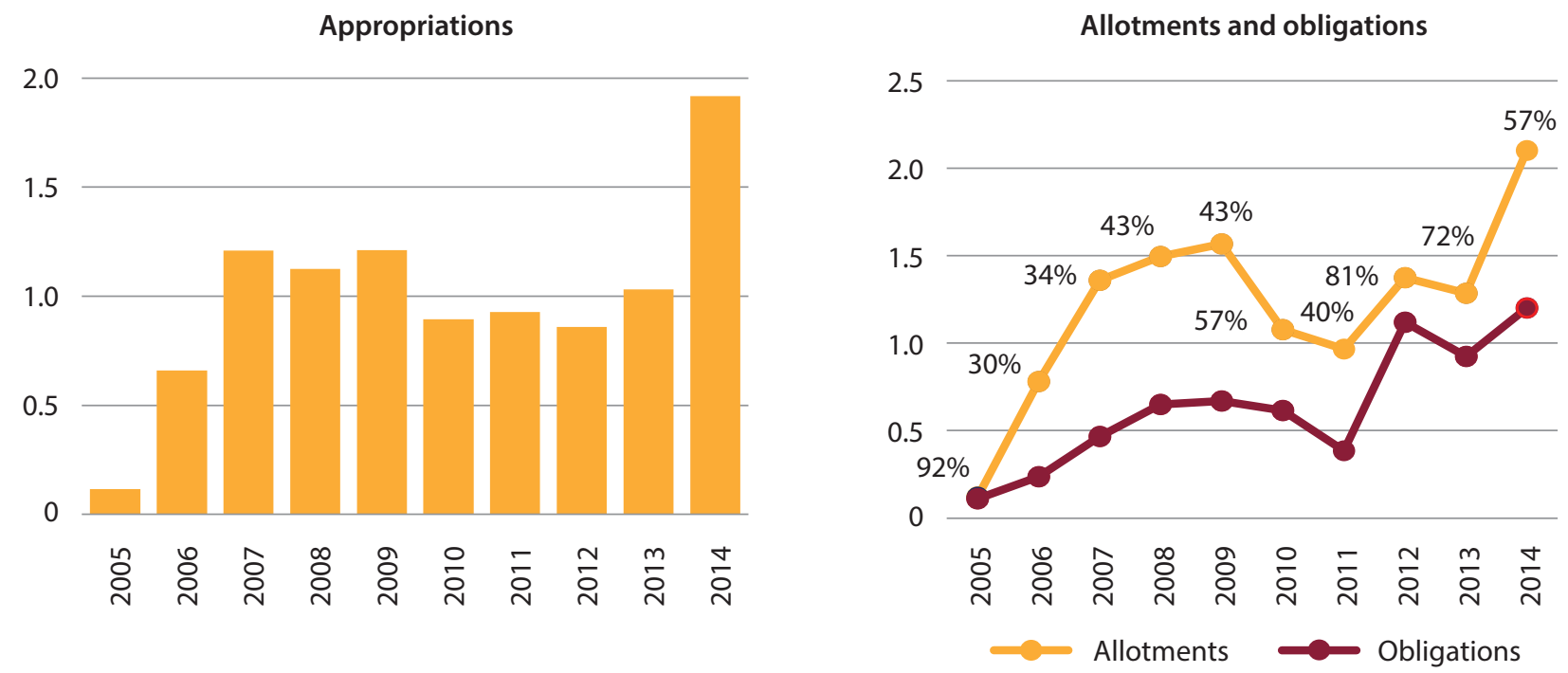

Source: Appropriations - Department of Budget and Management. All other data - DepEd Statement of Appropriations and Obligations, various years. Note: Allotments/obligations for a given year include current, continuing, and extended allotments/obligations. The utilization rate is indicated by the percentage figures in the graph and show the proportion of allotments obligated in a given year.

for more in-service training related to the new $\mathrm{K}$ to 12 curriculum. While all these funds are not solely for the use of in-service teacher training they represent approximately PHP 3,000 (US\$70) for every public basic education teacher.

However, the utilization of these funds fluctuates considerably. HRTD funds are managed by DepED's central office, and a portion are downloaded or transferred to DepEd's regional offices and onward to division offices for training activities. ${ }^{17}$ This process of downloading has often been delayed, which has resulted in relatively low utilization rates. For example, between 2005 and 2014, the average utilization rate for HRTD funds was only 55 percent (Figure 7). Even in 2014 after the significant increase in the HRTD appropriation, only 57 percent of the budget was used because of delays in downloading these funds.

The PETS-QSDS data revealed that DepEd's allocations of HRTD funds to each region are positively correlated with the number of public school teachers in each region. Regions with a larger number of teachers received a larger HRTD allocation. However, it was not possible to assess whether HRTD funds were also allocated according to the different professional development needs of teachers in each region.

The PETS-QSDS survey also tracked the flow of HRTD funds and found that a relatively small share is downloaded to DepEd division offices. In 2014, about half of all HRTD funds were allocated for training activities provided at DepEd's central office. The remainder of the HRTD funds was split relatively equally between DepEd's regional offices and division offices. Given that division offices and their staff have the most contact with schools and are thus most likely to know their in-service training needs, it is surprising that a larger share of HRTD funds is not downloaded to divisions.

On the whole, the tracking exercise also found that all HRTD funds that DepEd central office downloaded to regional offices were received in full. The specific amounts released by DepEd central office closely matched the amounts that the regional offices reported receiving. However, two regional offices did not report having received any funds even though records in the central office showed that funds had been transferred to them. This is more likely to be due to poor record keeping in DepEd regional offices than to be a leakage of funds. 
The share of HRTD funds downloaded from DepEd's regional offices to division offices varies enormously (Figure 8). In total, around 58 percent of the regional HRTD funds that are received by DepEd regional offices are downloaded to DepEd division offices. However, the proportion of funds that regional offices retain varies enormously. Some regions retain all of their HRTD funding and do not download any funding for division offices, while other regions download all of their HRTD funds and the responsibility for their use to division offices.

Little information is available on how DepEd's regional offices used their retained HRTD funds. The regional offices retained approximately 42 percent of all of the HRTD funds that they received from DepEd central office rather than downloading them to division offices. DepEd expects regional offices to use these funds to organize mass teacher training on, for example, the introduction of the new K to 12 curriculum. DepEd's guidelines governing the use of these funds require regional offices to keep detailed records on who has been trained and the kind of training provided. However, when the PETS-QSDS study team visited all regional offices to collect this information, no such information was available. This lack of records greatly reduces the transparency of the use of these funds.
Significant delays in the allotment process account for the relatively low utilization rate of HRTD funds. Fewer than 15 percent of regional offices had received their HRTD allotment from DepEd's central office by the end of the first quarter of 2013 (Figure 9). However, by the end of the second quarter, all regional offices had already received their allotments and most had downloaded funds to at least some of their division offices. However, 19 percent of the divisions that received HRTD funds received their allotment a year after the regional office first received its transfer of funds from DepEd's central office.

These delays can happen because the regional offices of the Department of Budget Management (DBM) are required to carefully check the funds requested by DepEd's central and regional offices on the Sub-Allotment Release Orders (SARO). Further delays occur because of the late release of cash allocations. One-fifth of the DepEd division offices that had received their HRTD allotments for 2013 at the time of the PETS-QSDS survey had not received the associated release of funds (notice of cash allocations) needed to use or obligate the funds. The difficulties in using the allotted funds are particularly concerning given the clear need for in-service training that was highlighted by the PETS-QSDS teacher content knowledge assessments.

Figure 8: The Share of Regional HRTD Funds Transferred to Division Offices Varies Enormously Amounts of HRTD funds received by DepEd regional offices and transferred to DepEd division offices, 2013

\section{Received by DepEd regional offices (PHP millions)}

80

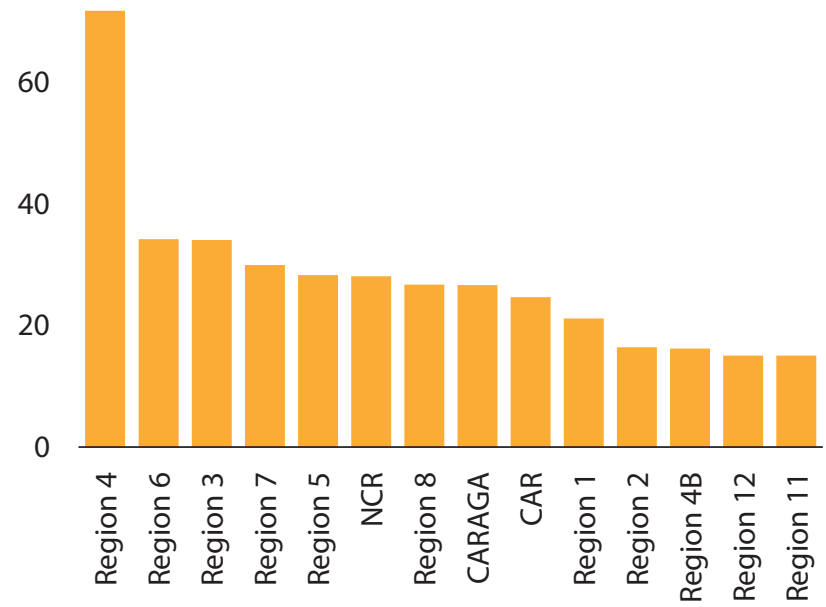

\section{Share downloaded to division offices}

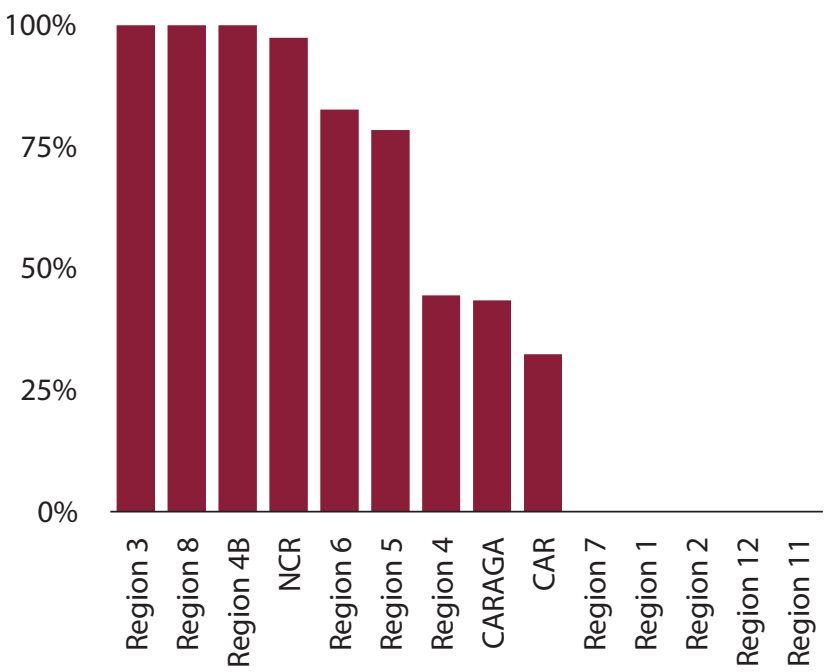

Source: PETS-QSDS national survey - DepEd regional office level.

Note: The information on the HRTD funds received by Region 7 from the central office is taken from the central office database because some information was missing from the regional questionnaire. Only regions reporting receipt of HRTD funds are included. 
Figure 9: A Significant Number of Division Offices Receive HRTD Funds Very Late in the Financial Year Percentage of division offices receiving 2013 HRTD funds by the quarter during which it was received

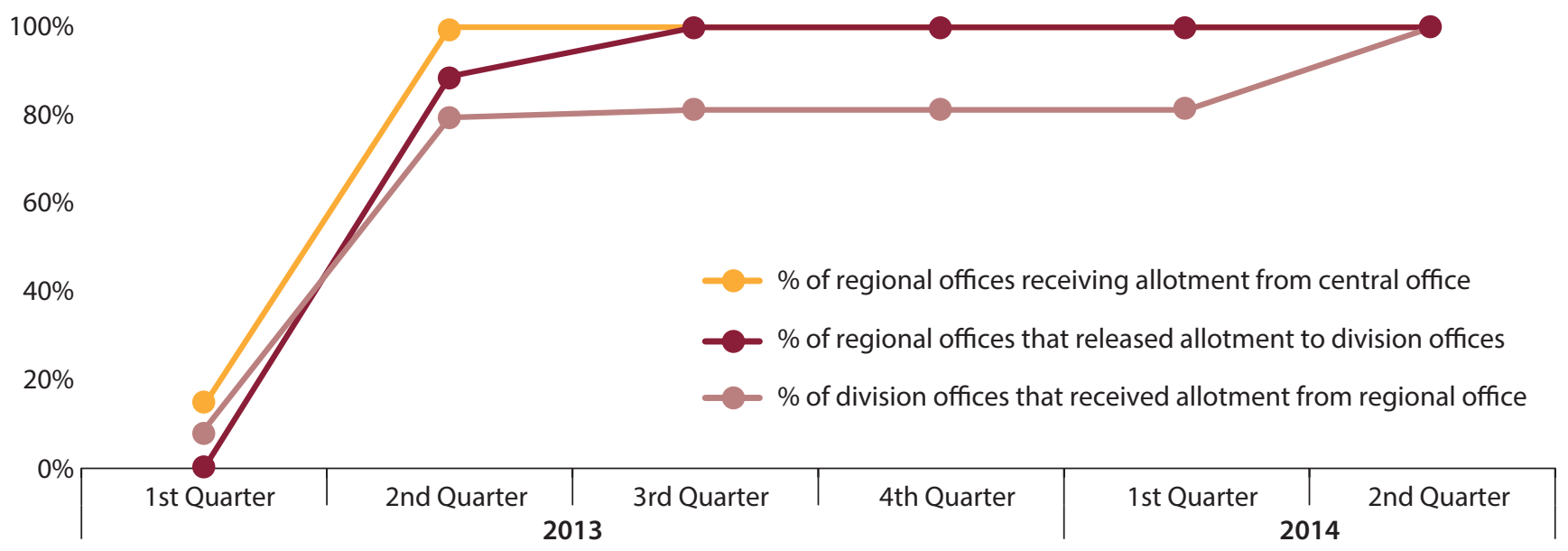

\section{Teacher Remuneration}

The level and timeliness of salary payments can be an important factor in motivating teachers, which in turn can affect levels of student learning. The PETS-QSDS study did not formally track teachers' salaries but did ask a nationally representative sample of teachers some questions about the adequacy of their salary payments and whether they received their salaries on time and in full.
Cross-country comparisons indicate that teachers in the Philippines are relatively well paid but their salary scale is more compressed. Comparable information on other East Asian countries shows that the starting salary of teachers in the Philippines is relatively high. For example, the average earnings of a newly hired elementary school teacher in the Philippines is equivalent to 150 percent of per capita GDP compared with only around 50 percent in Indonesia, Malaysia, and Thailand (Figure 10). However, earnings do

\section{Figure 10: Teacher Salaries Tend to be Higher in the Philippines than in Other Countries in the Region} Elementary school teacher salaries as a percentage of per capita GDP, 2010

$300 \%$

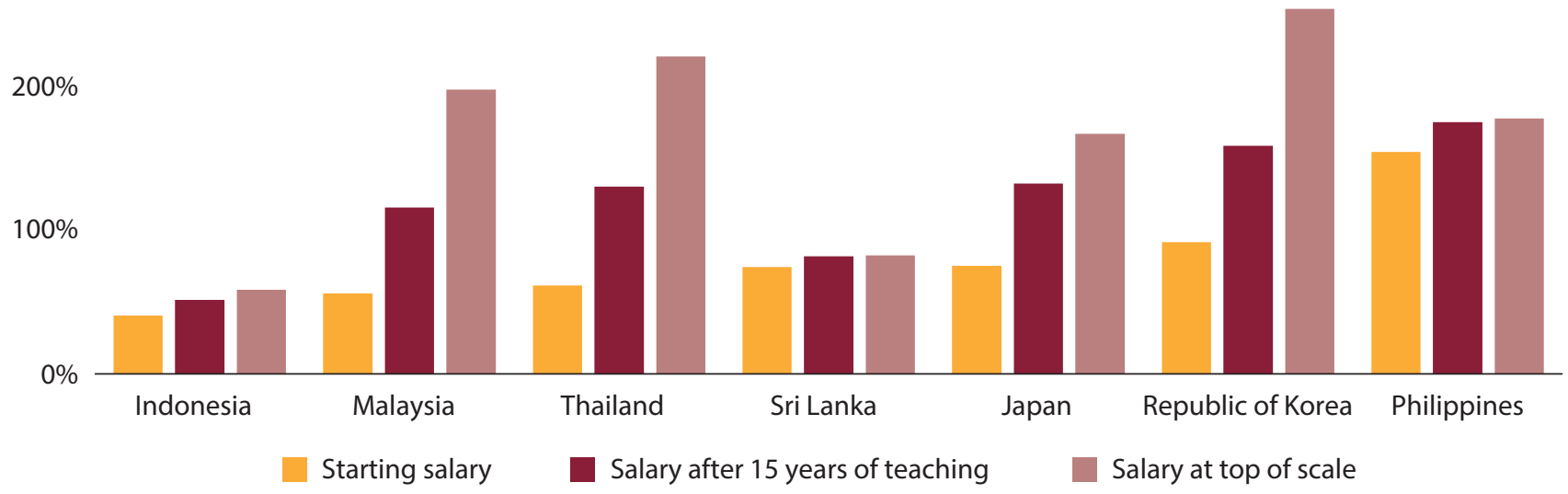

Source: UNESCO (2012). "Global Education Digest," UNESCO Institute for Statistics, Montreal. 
not increase very quickly after teachers are hired. After 15 years, salaries increase by only 15 percent in the Philippines, which is low compared to other countries. These relatively small salary increases over the course of a teacher's career are unlikely to motivate them significantly. The PETS-QSDS study found that high school teachers with a post-graduate degree felt that their remuneration was not adequate.

Moreover, about one-fifth of teachers reported that they had to have other jobs or sources of income to supplement their earnings from teaching.

However, teachers also receive a bonus based on their school's ranking on a set of performance-based indicators including how well the school's students score on the National Achievement Test. Teachers' performance-based bonuses in 2015 ranged from PHP 5,000 to PHP 35,000, which was equivalent to between 1 and 9 percent of a teacher's average annual salary. ${ }^{18}$

Teachers' motivation can also be affected by the timeliness of their salary payments. The PETS-QSDS study found that, while the majority of teachers were paid on time, 40 to 50 percent of newly hired kindergarten and elementary school teachers received their salaries late (Figure 11).

\section{Figure 11: Some Teachers Experienced Delays in Receiving their Salaries and Others Were Still Owed Back Payments} Percentage of teachers whose salary payments were late, 2014

$60 \%$

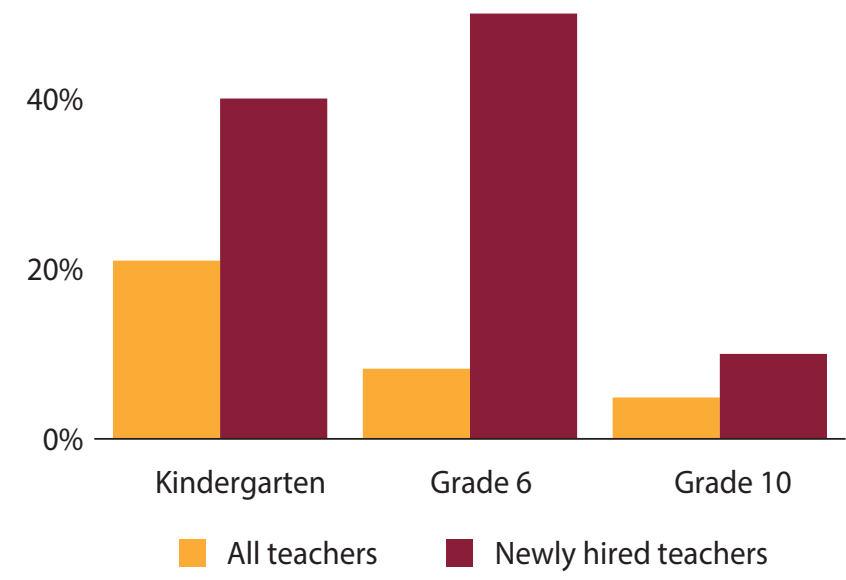

Source: PETS-QSDS data from DepEd teacher questionnaires for sampled teachers, 2014.
Most teachers also reported that they had been paid correctly and were not owed any salary payments. Only around 11 percent of elementary and high school teachers reported that they were owed salary payments from the government. However, the length of the delay was much longer for elementary school teachers than for high school teachers. Elementary school teachers had to wait an average of six months for their salary payments compared with a four-month wait for high school teachers.

\section{Policy Directions for Strengthening Systems to Support Teacher Development}

This note has shown that teacher competencies are weak and that systems to support teacher development are inadequate. While some of the gaps in teacher competencies are partly due to weaknesses in pre-service teacher training and induction, more efforts need to be made to increase the support available to teachers who are already teaching in schools.

A first step would be to raise levels of funding to increase both the duration and quality of in-service training for basic education teachers. As this note has shown, a significant proportion of HRTD funds are used for training that is organized at the regional level and above. Previous studies have found that the most successful professional development models are provided within schools or at the local level. They also provide opportunities for teachers to collaborate and support each other in implementing new knowledge and techniques at the school level. ${ }^{19}$

Providing divisions and schools with a larger share of professional development funding would make training more relevant and thus result in more substantial improvements in teachers' competencies. DepEd could revise its guidelines on the use of HRTD funds to require DepEd's regional offices to download a larger proportion of these funds to divisions and schools. Currently the DepEd guidelines encourage the provision of mass training at the regional level, which makes the training too remote from the actual needs of teachers at the school level. If more funds 
are provided to DepEd's division offices and schools, it will also be vital to improve the timeliness of fund release to give the recipients time to properly plan and implement their professional development activities.

DepEd is currently establishing "school learning action cells" in elementary schools to strengthen early grade learning outcomes. These cells, or groups, of kindergarten to grade 3 teachers meet regularly and provide opportunities for members to learn from each other and to collaborate on strategies to improve teaching and learning. These school learning action cells have the potential to increase the quantity and improve the quality of in-service training opportunities for teachers. However, it is vital that these cells are monitored and evaluated closely by DepEd to ensure that their potential is fully realized.
This note has also shown that the monitoring of the use of HRTD funds has been weak and needs to improve if these resources are to be used more effectively. Information on who is being trained and the type of training being provided is often unavailable. This makes it impossible to monitor how the funds are being used and whether teachers' professional development needs are being met. Developing simple reporting formats for DepEd's regional and division offices to record how they use HRTD funds would greatly facilitate the monitoring and evaluation of in-service training provision by DepEd.

The existing system for identifying and planning professional development activities needs to be strengthened. This note has shown that the TSNA may not be adequate for identifying teachers' professional development needs. Developing a

\section{Box 3: Indonesia's Integrated Framework for Teacher Accountability}

The Ministry of Education in Indonesia is starting to implement its integrated Teacher Professional Management System (TPMS). The system consists of three main elements:

- Competency Testing. Teachers are expected to undergo a competency assessment to identify their strengths and weaknesses. The competency test is focused on teachers' subject knowledge, which has been shown to be strongly related to student learning outcomes. Performance on the competency test is expected to be used as one of the key criteria for teachers' career advancement.

- Performance Appraisal. A school-based scheme has been piloted that links the outcomes of teachers' annual performance appraisal to increments in the salary scale in order to give them an incentive to improve their performance.

- Continuous Professional Development. This component covers a number of different aspects of in-service teacher training including the induction of teachers into schools, mentoring, and the activities of local teacher working groups.

The aim of the TPMS is to link these three components together and make teachers more accountable for both their work performance through the annual appraisal and for taking advantage of in-service training opportunities. By scoring well on their appraisals and by participating in training, teachers can earn credit points that are ultimately linked to salary increases and promotion. While the TPMS is not yet being fully implemented, it represents a major development in terms of the provision of incentives and is expected to increase the motivation of teachers to improve how they teach. Integrating continuous professional development into the TPMS framework has also provided the government with the information necessary to target teachers' professional development activities better.

It is expected that the TPMS will sustain the momentum towards improving the quality of teachers in Indonesia and will establish a quality assurance mechanism that will ensure higher education standards well into the future.

Sources: Ragatz, A. (2015). "Teacher Quality and Management. Background Study for the Preparation of the Education Chapter of the National Development Plan, 2015-2019." Jakarta, Ministry of Planning, Republic of Indonesia., and Chang, M.C., S. Shaeffer, S. Al-Samarrai, A. Ragatz, J. de Ree, and R. Stevenson (2013). "Teacher Reform in Indonesia: The Role of Politics and Evidence in Policy Making." Directions in Development. World Bank, Washington, D.C. 
diagnostic teacher competency assessment to better identify teachers' in-service training needs could support improvements in this area. Moreover, neither teachers nor schools seem to be routinely preparing their professional development plans, and these plans do not seem closely related to the in-service training opportunities currently being provided. Greater efforts need to be made to ensure that teachers and schools use these plans to help division offices to plan in-service training opportunities better.

Stronger links between teacher performance appraisals, professional development opportunities and career development for teachers may create stronger incentives for teachers, school principals and administrators to utilize these systems and strengthen professional development opportunities. For example, individual and school plans for professional development and their implementation could be used more specifically in decisions over promotion or in determining performance bonuses (see Box 3).

Increasing the number and effectiveness of teachers has been a central component of efforts in the Philippines to raise the quality of basic education. While significant improvements have been made in terms of the number and distribution of teachers, there is an urgent need to provide greater support to teachers to improve their competencies and effectiveness in the classroom. Only then will efforts to provide adequate teachers to all schools translate into better quality and improved learning outcomes.

\section{Table 1: Strengthening Teacher Support Systems}

\begin{tabular}{|c|c|}
\hline Findings & Policy suggestions \\
\hline $\begin{array}{l}\text { Teacher subject knowledge } \\
\text { is generally low }\end{array}$ & - Strengthen pre-service and in-service training opportunities for all teachers (see below) \\
\hline $\begin{array}{l}\text { Professional development } \\
\text { opportunities are limited } \\
\text { and delivery mechanisms are } \\
\text { weak }\end{array}$ & $\begin{array}{l}\text { - Increase funding and opportunities for effective professional development for teachers } \\
\text { - Provide a greater share of this funding to division offices and schools to enable them to } \\
\text { organize professional development activities } \\
\text { - Transfer HRTD funds in a more timely manner } \\
\text { - Increase the transparency of HRTD funds through improved reporting by DepEd region } \\
\text { and division offices and increase central office monitoring of fund use }\end{array}$ \\
\hline $\begin{array}{l}\text { Systems to identify teachers' } \\
\text { professional development } \\
\text { needs are weak }\end{array}$ & $\begin{array}{l}\text { - Revaluate existing teacher strength and needs assessments and teacher professional } \\
\text { development planning } \\
\text { - Develop diagnostic teacher competency tests to identify teachers' in-service training } \\
\text { needs } \\
\text { - Develop content for professional development activities that will address existing } \\
\text { weaknesses } \\
\text { - Evaluate and scale up the use of school learning action cells as the main venue for in- } \\
\text { service training }\end{array}$ \\
\hline $\begin{array}{l}\text { A greater need to align } \\
\text { teacher accountability } \\
\text { systems to raise teacher } \\
\text { motivation and competencies }\end{array}$ & $\begin{array}{l}\text { - Support a stronger alignment between professional development planning, career } \\
\text { development and performance incentives }\end{array}$ \\
\hline
\end{tabular}




\section{Endnotes}

1 See for example, Bruns, B. and J. Luque (2014). "Great Teachers: How to Raise Student Learning in Latin America and the Caribbean."World Bank, Washington D.C.

2 De Ree, J. (2016). "How Much Teachers Know and How Much It Matters in Class: Analyzing Three Rounds of Subject-specific Test Score Data of Indonesian Students and Teachers." Policy Research Working Paper No. WPS 7556. World Bank, Washington D.C.

3 Chetty, R., J. Friedman, and J. Rockoff. (2011). "The Long-Term Impacts of teachers: Teacher Value-added, and Student Outcomes in Adulthood," National Bureau of Economic Research, Cambridge MA.

4 See, for example, McEwan, P. (2013). "Improving Learning in Primary Schools of Developing Countries: A Meta-Analysis of Randomized Experiments."Wellesley College, Wellesley MA. Glewwe, P.W., E. A. Hanushek, S.D. Humpage, and R. Ravina. (2011). "School Resources and Educational Outcomes in Developing Countries: A Review of the Literature from 1990 to 2010." National Bureau of Economic Research, Cambridge MA.

5 Another note in this series assesses the systems used to hire and deploy teachers in the Philippines.

6 See for example, Yamauchi, F. and Y. Liu (2013). "Impacts of an Early Stage Education Intervention on Students'Learning Achievement: Evidence from the Philippines." Journal of Development Studies 49(2) and Tan, J. P., J. Lane, and P. Coustere. (1997). “Putting Inputs to Work in Elementary Schools: What Can Be Done in the Philippines?" Economic Development and Cultural Change 45(4): 857-879.

7 The full results of the analysis reported here is included in a set of additional annexes and tables accompanying the main PETSQSDS report.

8 The household questionnaire included a short module on consumption and a set of questions on assets that have been used by the Department of Social Welfare and Development (DSWD) to undertake a proxy means testing (PMT) approach to estimating household consumption per capita. The results reported here are based on information gathered using the PMT approach, and a full description is included in a separate note.

9 These results are statistically significant for Filipino and Mathematics but not for Science.

10 Box 2 describes all seven domains contained in the teacher competency standards. All teachers rated their skills in the professional development and growth domain highly. These results are not discussed in this note.
11 See, for example, McEwan, P. (2013) "Improving Learning in Primary Schools of Developing Countries: A Meta-Analysis of Randomized Experiments"Wellesley College, Wellesley, MA; Glewwe, P.W., E. A. Hanushek, S.D. Humpage, and R. Ravina (2011) "School Resources and Educational Outcomes in Developing Countries: A Review of the Literature from 1990 to 2010"National Bureau of Economic Research, Cambridge MA; and the Council of Chief State School Officers (2009) "A Meta-Analysis Study of the Effects of Teacher Professional Development with a Math or Science Content Focus on Improving Teaching and Learning." Washington D.C.

12 OECD (2014). TALIS 2013 Results: An International Perspective on Teaching and Learning, OECD Publishing, Paris.

13 OECD (2014). "TALIS 2013 Results: An International Perspective on Teaching and Learning." OECD Publishing, Paris.

14 The sampled teachers were asked to rank each training they attended from 1 (least useful) to 7 (most useful). Grade 6 teachers rated 88 percent of all training as a 6 or 7 with 84 percent of Grade 10 teachers doing the same.

15 Just under 90 percent of school principals reported that teachers were expected to complete an IPPD annually.

16 Similar results were found when school principals were asked the same questions.

17 Downloading refers to the issuance of a sub-allotment release order from DepEd central office to DepEd region and division offices. Sub-allotments are authorizations issued by the central office of DepEd transferring a portion of an available allotment to DepEd region or division offices. See DepEd order No. 25 (2014) "Guidelines for the Utilization of HRTD Funds," Department of Education, Manila and DepEd order No. 66 (2010) "Policies and Guidelines on Planning and Administration/Management of the Human Resource Training and Development Program," Department of Education, Manila.

18 Based on the average annual basic salary of a Teacher 1 position on Grade 18 Step 8.

19 Blank, R. and N. Alas (2009). "Effects of Teacher Professional Development on Gains in Student Achievement." Report prepared for the Council of Chief State School Officers (CCSSO), Washington D.C.

\section{(4) WORLD BANK GROUP}

\section{Australian \\ AlD}

